\title{
PENGARUH PERBEDAAN STATER TERHADAP PRODUKSI BIOGAS DENGAN BAHAN BAKU ECENG GONDOK
}

\author{
Dwi Irawan', Teguh Santoso. ${ }^{2)}$ \\ Program Studi Teknik Mesin, Fakultas Teknik, Universitas Muhammadiyah Metro. ${ }^{1,2)}$ \\ Jl. Ki Hajar Dewantara 15 A Metro, Lampung. \\ dwi_irawan12@yahoo.co.id
}

\begin{abstract}
Abstrak
Dalam dekade terakhir, tingkat konsumsi energi semakin tinggi sedangkan sumber energi fosil semakin terbatas. Oleh karna itu di perlukan usaha-usaha untuk mendapatkan energi terbarukan. Disisi lain banyak limbah yang dapat dibuat biogas yang merupakan energi terbarukan. Eceng gondok (Eicchornia crassipes) merupakan jenis gulma yang pertumbuhannya sangat cepat. Akan tetapi eceng gondok dapat dimanfaatkan dalam produksi biogas karena mempunyai kandungan hemiselulosa yang cukup besar. Pencernaan anaerobik adalah proses dimana mikroorganisme memecah bahan dalam ketiadaan oksigen. Proses pembuatan biogas dimulai dari pembuatan digester, proses pengambilan eceng gondok dengan mencacah eceng gondok, penyediaan stater EM4 dan stater kotoran sapi. Tujuan penelitian ini adalah untuk mengetahui tekanan biogas yang dihasilkan, mengetahui pengaruh perbedaan bioaktivator EM4 dan kotoran sapi terhadap produksi biogas dan mengetahui berapa laju aliran massa biogas yang dihasilkan. Pada penelitian ini terdapat 3 variabel percobaan, dimana percobaan I dengan perbandingan bahan 1:1 (eceng gondong cacah $20 \mathrm{~kg}$, air $20 \mathrm{~kg}$ ) dan penambahan stater EM4 3,6 kg, selanjutnya pada percobaan II dengan perbandingan bahan $1: 1$ (eceng gondong cacah $20 \mathrm{~kg}$, air $20 \mathrm{~kg}$ ) dan penambahan stater kotoran sapi $6 \mathrm{~kg}$, sedangkan pada percobaan III menggunakan perbandingan bahan $1: 1$ (eceng gondong cacah $20 \mathrm{~kg}$, air $20 \mathrm{~kg}$ ) dengan penambahan stater EM4 1,8 kg dan stater kotoran sapi $3 \mathrm{~kg}$. Hasil yang didapat pada variabel percobaan I dengan tekanan biogas sebesar 104165,72 N/m ${ }^{2}$ dengan massa biogas diperoleh $0,379034 \mathrm{~kg}$ dan diperoleh laju aliran massa biogas mencapai $0,0126345 \mathrm{~kg} / \mathrm{hari}$, sedangkan percobaan II dengan tekanan biogas sebesar 103139,4 N/ $\mathrm{m}^{2}$ menghasilkan massa biogas 0,375274 $\mathrm{kg}$ dan diperoleh laju aliran massa biogas mencapai 0,0125091 kg/hari selanjutnya pada percobaan III dengan tekanan biogas sebesar $102324,98 \mathrm{~N} / \mathrm{m}^{2}$ menghasilkan massa biogas $0,372266 \mathrm{~kg}$ dan memperoleh laju aliran massa biogas mencapai $0,0124089 \mathrm{~kg} / \mathrm{hari}$. Berdasarkan hasil penelitian dalam ketiga percobaan penambahan dua stater yang berbeda yaitu lebih efektif pada percobaan I dengan penambahan stater EM4 yang menghasilkan tekanan mencapai $104165,72 \mathrm{~N} / \mathrm{m}^{2}$ dengan massa biogas sebesar 0,379034 $\mathrm{kg}$ dan laju aliran massa mencapai 0,0126345 kg/hari
\end{abstract}

Kata Kunci : Biogas; EM4; Kotoran Sapi; Eceng Gondok

\section{PENDAHULUAN}

Meningkatnya kebutuhan energi dan semakin tingginya perhatian publik terhadap menipisnya persediaan sumber energi sehingga tidak dapat dipungkiri energi sangat berperan penting dalam membantu berbagai alat pendukung yang memerlukan energi, Untuk mengembangkan sumber energi yang dapat diperbaharui sebagai alternatif pengganti bahan bakar minyak salah satu sumber energi altrnatif adalah biogas. Biogas merupakan energi terbarukan yang dapat dihasilkan dengan teknologi tepat guna yang relatif lebih sederhana. Energi biogas adalah memproses limbah bio yang terbentuk karena proses fermentasi dalam alat kedap udara (anaerobik) yang disebut digester untuk menghasilkan campuran dari beberapa gas yaitu metan $\left(\mathrm{CH}_{4}\right)$ atau methanobacterium dan karbon dalam biogas merupakan karbon yang diambil dari atmosfer oleh fotosintesis tanaman, sehingga bila dilepaskan lagi ke atmosfer tidak akan menambah jumlah karbon di atmosfer.

Salah satu tumbuhan atau bahan organik yang cukup berpotensi untuk menjadi bahan baku pembentukan biogas diantaranya tumbuhan eceng gondok. Eceng gondok (Eichhornia crassipes) merupakan salah satu jenis tumbuhan air mengapung. Dibalik efek negatif, namun beberapa kemungkinan nilai ekonomis yang dapat dimanfaatkan yaitu unsur metan yang terkandung pada eceng gondok dan cukup mengandung selulosa dalam jumlah yang cukup besar, kandungan solulosa inilah yang memiliki potensi sebagai pembuatan biogas. Untuk meningkatkan efisiensi dalam pembentukan biogas dari eceng gondok, memerlukan optimalisasi peranan dari mikroorganisme, hal ini dapat dilakukan dengan cara menambahkan stater. Dalam hal ini akan membandingkan atara 2 (dua) stater yang berbeda yaitu EM4 (Efective 
mikroorganisme4) dan kotoran sapi, dengan cara melakukan percobaan yang dalam setiap stater yang bertujuan untuk mengetahui pengaruh terbaik dari 2 (dua) stater tersebut.

Pada dasarnya dalam stater yang pertama yaitu EM4 (Efective mikroorganisme) terkandungan mikroba yang sangat efektif digunakan untuk bahan organik, limbah rumah tangga, limbah pasar, limbah pabrik, dan lainlain. EM4 berperan mempercepat degradasi atau fermentasi bahan organik dalam proses pembentukan biogas disebut sebagai biakan (starter), menekan perkembangan mikroorganisme patogen, dan sebagainya. Sedangkan pada penggunaan stater yang kedua yaitu kotoran sapi.

Pada dasarnya dimana penggunaan kotoran sapi sebagai bahan baku biogas cukup mengandung biakan mikroba-mikroba atau starter maupun biang didalamnya. Keadaan tersebut memberikan keterangan dalam kotoran sapi telah terdapat mikroba yang berperanan dalam proses produksi biogas. Adapun laju dari pembentukan biogas dapat dipengaruhi oleh beberapa faktor, diantaranya adalah suhu, rasio $\mathrm{C} / \mathrm{N}$ dan pengaruh pengadukan dalam selang waktu tertentu. Penelitian difokuskan untuk mengetahui perbandingan pengaruh penggunaan EM4 dan kotoran sapi sebagai stater dalam membantu pembentukan biogas, juga untuk mengetahui pengaruh campuran kedua stater tersebut pada proses pembentukan biogas agar dapat menghasilkan biogas secara optimum dari bahan organik eceng gondok. permasalahan yang ada.

Atas dasar pertimbangan tersebut, maka penulis akan meneliti Berapa tekanan biogas yang dihasilkan, bagaimana pengaruh perbedaan bioaktivator EM4 (efective micrrorganisme 4) dan kotoran sapi terhadap produksi biogas dari bahan organik eceng gondok dan berapa laju aliran massa biogas yang dihasilkan.

\section{LANDASAN TEORI \\ Bahan Organik}

Yang termasuk kategori bahan organik misalnya, tumbuh-tumbuhan, buah-buahan, jerami, sekam dan lain-lain. Adapun yang termasuk dalam bahan organik yaitu tumbuhan eceng gondok.

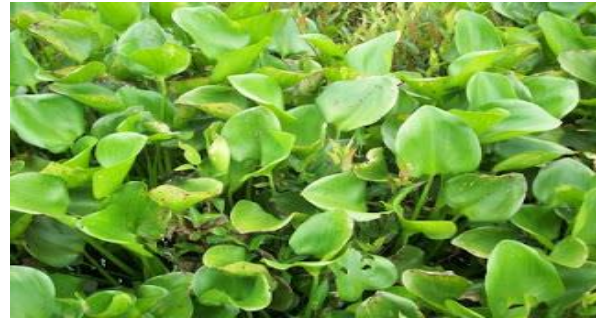

Gambar 1. Eceng Gondok

Eceng gondok atau (Eichhornia crassipes) adalah salah satu jenis tumbuhan air mengapung. Eceng gondok memiliki kecepatan tumbuh yang tinggi sehingga tumbuhan ini dianggap sebagai gulma yang dapat merusak lingkungan perairan.

Namun beberapa kemungkinan nilai ekonomis, dimana jenis tanaman yang masih belum memiliki nilai jual yang tinggi ini ternyata cukup mengandung hemi selulosa dalam jumlah yang cukup besar dan kandungan hemi solulosa inilah yang memiliki potensi sebagai pembuatan biogas sebagai bahan bakar alternatif. (Arnold Yonathan, dkk : 2013)

\section{Efective Microoganisme (EM4)}

Efective Microoganisme (EM4)
berperan mempercepat degradasi atau fermentasi bahan organik dalam proses pembentukan biogas disebut sebagai biakan (starter).

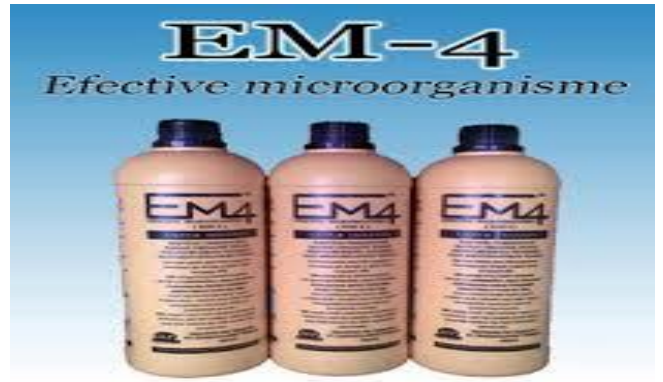

Gambar 2. EM4 (Efective mikroorganisme)

Mikroorganisme atau kuman yang berwatak "baik" itu terdiri dari bakteri fotosintetik, bakteri asam laktat, ragi, aktinomydetes, dan jamur peragian. Kandungan EM4 terdiri dari bakteri fotosintetik, bakteri asam laktat, actinomicetes, ragi dan jamur fermentasi yang mampu mengaktifkan bakteri pelarut sehingga merangsang pertumbuhan mikroorganisme.

Untuk melakukan degradasi senyawasenyawa organik terutama untuk bahan organik, EM4 ini lebih cepat dari pada yang dilakukan oleh mikro organisme alami yang terdapat dalam bahan organik tersebut. Dalam 
penambahan EM4 dapat menghasilkan volume biogas yang paling optimum. Hal ini terjadi karena ketersediaan jumlah bahan organik yang didegradasi dalam keadaan seimbang dengan jumlah pertumbuhan mikroorganisme dalam bahan organik.

Tabel 1. Rerata biogas pada variasi konsentrasi EM4

\begin{tabular}{|l|l|l|l|}
\hline \%EM4 & Biogas (ml) & \%EM4 & Biogas (ml) \\
\hline Kontrol & & & \\
\hline $2,5 \%$ & 136.67 & 6,5 & 222.17 \\
\hline $3 \%$ & 157 & 7 & 231.67 \\
\hline $3,5 \%$ & 158 & 7,5 & 239.5 \\
\hline $4 \%$ & 164.83 & 8 & 245.17 \\
\hline $4,5 \%$ & 173.17 & 8,5 & 257.5 \\
\hline $5 \%$ & 176.17 & 9 & 328.17 \\
\hline $5,5 \%$ & 187.67 & 9,5 & 201.67 \\
\hline $6 \%$ & 188.17 & 10 & 193.33 \\
\hline
\end{tabular}

Sumber : I Gusti Made Sanjaya, 2010

\section{Kotoran Sapi}

Kotoran sapi adalah limbah hasil pencernaan sapi dan hewan dari subfamily. Dimana baru-baru ini penggunaan kotoran sapi sebagai starter didasarkan atas proses produksi biakan mikroba atau starter maupun biang. Keadaan tersebut memberikan keterangan dalam kotoran sapi telah terdapat mikroba yang berperanan dalam proses produksi biogas.

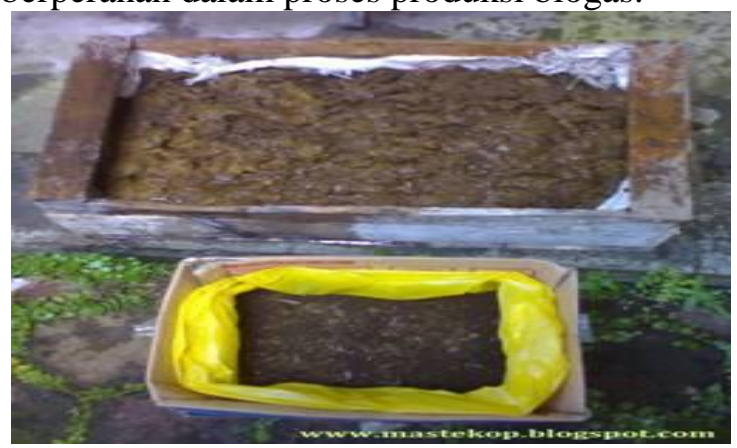

Gambar 3. Kotoran Sapi

Substrat dalam kotoran sapi telah mengandung bakteri penghasil gas metana yang terdapat di dalam perut hewan ruminansia. Keberadaan bakteri di dalam usus besar ruminansia tersebut membantu proses fermentasi, oleh karena itu kotoran sapi dapat juga digunakan sebagai pemicu atau stater sehingga proses pembentukan gas bio pada digester dapat dilakukan lebih cepat.

Selain itu kotoran dalam kondisi segar lebih mudah diproses dibandingkan dengan kotoran yang lama dan atau dikeringkan, disebabkan karena hilangnya substrat volatil solid selama waktu pengeringan.
Tabel 2. Rerata produksi biogas dengan stater kotoran sapi

\begin{tabular}{|c|l|l|c|c|c|}
\hline $\begin{array}{c}\text { Kosentrasi } \\
\text { Stater } \\
\text { Kotoran } \\
\text { sapi (\%) }\end{array}$ & \multicolumn{5}{|c|}{ Berat gas hari ke (gr) } \\
& \multicolumn{5}{|c|}{} \\
\cline { 2 - 6 } & 10 & 15 & \multicolumn{5}{|c|}{25} & \\
\hline 5 & 2,33 & 4,67 & 8,00 & 11,33 & 18,00 \\
\hline 10 & 3,67 & 6,00 & 9,33 & 13,00 & 19,67 \\
\hline 15 & 3,67 & 6,00 & 10,33 & 14,00 & $\mathbf{2 0 , 6 7}$ \\
\hline
\end{tabular}

Sumber : Sakinah, 2012

\section{Perbandingan Stater}

Dalam pebuatan biogas untuk mempercepat degradasi bahan baku biogas yang digunakan maka dibutuhkan mikroorganisme yang dapat disebut sebagai biakan atau stater. Pada penelitian sebelumnya yang dilakukan oleh I Gusti Made Sanjaya bahwa EM4 (effektive micro organisme) dapat mempercepat proses fermentasi bahan baku menjadi biogas. Kondisi optimum yang dihasilkan adalah melakukan penambahan EM4 (effektive micro organisme) dengan kosentrasi sebanyak $9 \%$.

Begitu pula hal yang sama penelitian sebelumnya yang dilakukan oleh Sakinah pada penambahan kotoran sapi sebagai stater dalam produksi biogas. Bahwa efektifitas pembentukan biogas ditentukan oleh jenis dan kosentrasi stater, dalam penggunaan kotoran sapi sebagai stater menghasilkan produksi biogas lebih besar pada kosentrasi sebanyak $15 \%$.

\section{METODE PENELITIAN}

Penelitian ini dilakukan dengan bentuk penelitian eksperimental, yang menggunakan bahan diantaranya eceng gondok cacah, air, stater EM4 dan stater kotoran sapi sebagai bahan baku pembuatan biogasnya.

Selain itu penelitian ini terdiri dari tiga percobaan yaitu pada percobaan pertama dengan perbandingan bahan $1: 1$ (eceng gondong cacah $20 \mathrm{~kg}$, air $20 \mathrm{~kg}$ ) dan penambahan stater EM4 3,6 kg kemudian pada percobaan kedua menggunakan perbandingan bahan 1 : 1 (eceng gondong cacah $20 \mathrm{~kg}$, air $20 \mathrm{~kg}$ ) dan penambahan stater kotoran sapi $6 \mathrm{~kg}$ selanjutnya pada percobaan ketiga dengan perbandingan bahan 1 : 1 (eceng gondong cacah $20 \mathrm{~kg}$, air 20 $\mathrm{kg}$ ) dengan penambahan EM4 1,8 kg dan stater kotoran sapi $3 \mathrm{~kg}$. 


\section{PERHITUNGAN DAN PEMBAHASAN}

Bervariasinya massa biogas yang dihasilkan dalam masing-masing percobaan pada setiap reaktor cukup menunjukan perbedaan hasil yang siknifikan. Dimana produksi biogas yang dihasilkan dapat dilihat pada tabel ketiga percobaan tersebut.

Tabel 3. Massa biogas perlima hari pada (percobaan pertama)

\begin{tabular}{|c|c|c|c|c|}
\hline No & $\begin{array}{c}\text { Hari } \\
\text { ke }\end{array}$ & $\begin{array}{c}\text { Temperatur } \\
\text { rata-rata } \\
\left({ }^{\circ} \mathrm{C}\right)\end{array}$ & $\begin{array}{c}\text { Tekanan } \\
\text { rata-rata } \\
\text { perlima hari } \\
\left(\mathrm{N} / \mathrm{m}^{2}\right)\end{array}$ & $\begin{array}{c}\text { Massa } \\
\text { biogas } \\
\text { perlima } \\
\text { hari }(\mathrm{kg}) \\
\end{array}$ \\
\hline 1 & 5 & 28 & 101710,5 & 0,06185 \\
\hline 2 & 10 & 29 & 102068 & 0,06198 \\
\hline 3 & 15 & 29 & 104477,9 & 0,06336 \\
\hline 4 & 20 & 30 & 107460,2 & 0,06504 \\
\hline 5 & 25 & 29 & 106990,3 & 0,06480 \\
\hline 6 & 30 & 29 & 102287,4 & 0,06199 \\
\hline \multicolumn{3}{|c|}{ Jumlah } & 104165,72 & 0,37903 \\
\hline
\end{tabular}

Tabel 4. Massa biogas perlima hari pada (percobaan kedua)

\begin{tabular}{|c|c|c|c|c|}
\hline No & $\begin{array}{l}\text { Hari } \\
\text { ke }\end{array}$ & $\begin{array}{c}\text { Temperatur } \\
\text { rata-rata } \\
\left({ }^{0} \mathrm{C}\right)\end{array}$ & $\begin{array}{c}\text { Tekanan } \\
\text { rata-rata } \\
\text { perlima hari } \\
\left(\mathrm{N} / \mathrm{m}^{2}\right)\end{array}$ & $\begin{array}{c}\text { Massa } \\
\text { biogas } \\
\text { perlima } \\
\text { hari }(\mathrm{kg})\end{array}$ \\
\hline 1 & 5 & 30 & 103545 & 0,062676 \\
\hline 2 & 10 & 29 & 103653,9 & 0,062905 \\
\hline 3 & 15 & 29 & 103809,1 & 0,062958 \\
\hline 4 & 20 & 28 & 103877,6 & 0,063208 \\
\hline 5 & 25 & 29 & 102226,5 & 0,061916 \\
\hline 6 & 30 & 29 & 101724,3 & 0,061612 \\
\hline \multicolumn{3}{|c|}{ Jumlah } & 103139,4 & 0,375274 \\
\hline
\end{tabular}

Tabel 5. Massa biogas perlima hari pada (percobaan ketiga)

\begin{tabular}{|c|c|c|c|c|}
\hline No & $\begin{array}{c}\text { Hari } \\
\text { ke }\end{array}$ & $\begin{array}{c}\text { Temperatur } \\
\text { rata-rata } \\
\left({ }^{\circ} \mathrm{C}\right)\end{array}$ & $\begin{array}{c}\text { Tekanan } \\
\text { rata-rata } \\
\text { perlima hari } \\
\left(\mathrm{N} / \mathrm{m}^{2}\right)\end{array}$ & $\begin{array}{c}\text { Massa } \\
\text { biogas } \\
\text { perlima } \\
\text { hari }(\mathrm{kg})\end{array}$ \\
\hline 1 & 5 & 28 & 102073,5 & 0,062112 \\
\hline 2 & 10 & 30 & 102648,6 & 0,06213 \\
\hline 3 & 15 & 29 & 102737,6 & 0,062349 \\
\hline 4 & 20 & 29 & 102979,9 & 0,062496 \\
\hline 5 & 25 & 29 & 101974,4 & 0,061763 \\
\hline 6 & 30 & 30 & 101535,9 & 0,061416 \\
\hline \multicolumn{3}{|c|}{ Jumlah } & 102324,9 & 0,372266 \\
\hline
\end{tabular}

Berdasarkan perhitungan yang dilakukan untuk mengetahui massa biogas dan laju aliran massa biogas maka dapat diperoleh hasil massa biogas yaitu untuk percobaan pertama massa biogas sebesar $0,379034 \mathrm{~kg}$ sedangkan untuk laju aliran massa biogas sebesar $0,0126345 \mathrm{~kg} / \mathrm{hari}$. Percobaan kedua massa biogas sebesar $0,375274 \mathrm{~kg}$ sedangkan untuk laju aliran massa biogas sebesar $0,0125091 \mathrm{~kg} / \mathrm{hari}$. Percobaan ketiga massa biogas sebesar $0,372266 \mathrm{~kg}$ sedangkan untuk laju aliran massa biogas sebesar 0,0124089 $\mathrm{kg} / \mathrm{hari}$.

Berdasarkan tabel 4.1, 4.2 dan 4.3 maka dapat dibentuk grafik perbandingan tekanan biogas diantaranya sebagai berikut

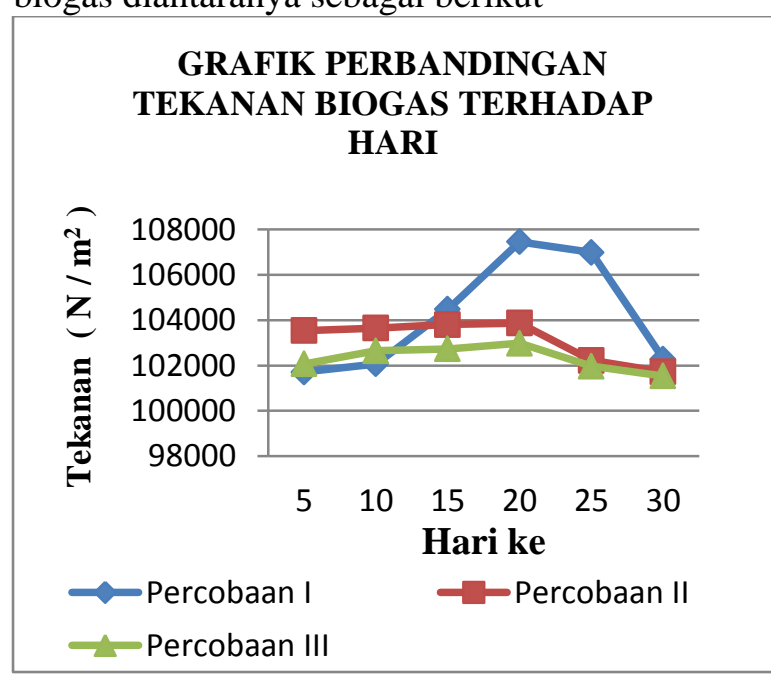

Gambar 4. Grafik perbandingan tekanan biogas sampai tiga puluh hari

Berdasarkan hasil penelitian yang dilakukan dari ketiga percobaan, hasil penelitian memperlihatkan bahwa tekanan biogas dari ke tiga percobaan tersebut cenderung meningkat terus seiring dengan bertambahnya waktu fermentasi yaitu sampai pada hari ke 20. Berdasarkan grafik tekanan dimana percobaan I dimana tekanan biogas mulai mengalami peningkatan yang cukup siknifikan pada lima hari ketiga sebesar 104477,9 N/m² memang lebih cepat pada percobaan II yang sudah memiliki tekanan yang cukup tinggi pada lima hari pertama sebesar $103545 \mathrm{~N} / \mathrm{m}^{2}$. Dalam hal ini disebabkan jumlah bakteri yang terkandung pada percobaan I lebih sedikit di banding pada percobaan II sehingga perkembang biakan dan degradasi dari selulosa, hemiselulosa dan lignin untuk dijadikan senyawa yang dibutuhkan oleh mikroorganisme penghasil biogas menjadi redah.

Maka dari itu semakin bertambahnya waktu fermentasi dan jumlah nutrient yang seimbang dengan jumlah mikroba yang ada serta konsentrasi padatan terlarut yang juga seimbang 
maka tekanan biogas tertinggi pada percobaan I yaitu pada pada lima hari keempat sebesar $107460,2 \mathrm{~N} / \mathrm{m}^{2}$. Justru pada percobaan ke II tekanan biogas tertinggi pada lima hari keempat sebesar 103877,6 N/m² lebih kecil dibandingkan pada percobaan I diduga karena jumlah mikroba tidak seimbang dengan nutrient yang sedikit.

Berbeda pada percobaan III, tekanan yang dihasilkan cenderung lebih kecil dibanding percobaan lainnya, sempat mengalami peningkatan pada lima hari kedua hanya saja tidak begitu tinggi yaitu $102648,6 \mathrm{~N} / \mathrm{m}^{2}$. Dalam hal ini diakibatkan jumlah mikroba yang tidak seimbang melebehi ketersedian nutrient yang lebih sedikit dan juga padatan terlarutnya cukup rendah sehingga perkembang biakan mikroba menurun yang mengakibatkan tekanan biogas rendah. Dapat dilihat dari hasil ketiga percobaan tersebut tekanan yang lebih tinggi yaitu pada percobaan 1 dengan tekanan sebesar 104165,72 $\mathrm{N} / \mathrm{m}^{2}$.

Selanjutnya berdasarkan tabel 4.1, 4.2 dan 4.3 maka dapat dibentuk grafik perbandingan massa biogasdiantaranya sebagai berikut :

\section{GRAFIK PERBANDINGAN MASSA BIOGAS TERHADAP HARI}

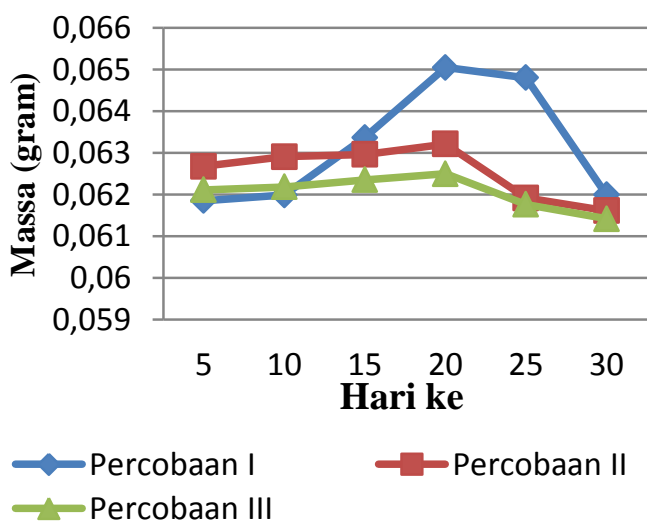

Gambar 5. Grafik perbandingan massa biogas sampai tiga puluh hari

Berdasarkan grafik hasil penelitian memperlihatkan bahwa laju produksi massa biogas dari ketiga percobaan tersebut cenderung meningkat terus seiring dengan bertambahnya waktu fermentasi yaitu sampai pada hari ke 20. Hasil penelitian memperlihatkan bahwa penambahan stater EM4 dan waktu fermentasi pada percobaan pertama cukup berpengaruh terhadap produksi biogas menggunakan eceng gondok sebagai bahan baku. Dari ketiga percobaan tersebut yang menghasilkan biogas terbesar yaitu pada percobaan pertama dengan menambahkan EM4 sebanyak 3,6 kg dimana hasil biogas tertinggi dihasilkan pada lima hari ke empat dengan rata-rata suhu reaktor $30{ }^{\circ} \mathrm{C}$ dengan tekanan yang mencapai 107460,2 N/m² dan menghasilkan biogas sampai $0,065043 \mathrm{~kg}$.

Penambahan stater EM4 sangat mempengaruhi terhadap peningkatan laju produksi biogas, hal ini disebabkan karena aktifitas EM4 yang terdiri atas Lactobacillus, Actinomycetes dan jamur. Fungsi mikroorganisme bertujuan untuk mempercepat degradasi selulosa, hemisolulosa, dan lignin menjadi senyawa yang dibutuhkan oleh mikroorganisme penghasil biogas, sehingga produksi biogas meningkat.

Berbeda dengan percobaan kedua dimana penambahan stater kotoran sapi sebanyak $6 \mathrm{~kg}$ cukup berpengaruh, hanya saja biogas yang dihasilkan tidak sebanyak pada percobaan pertama yang menggunakan penambahan stater EM4. Berdasarkan hasil pengamatan pada percobaan kedua sudah menghasilkan biogas cukup besar yaitu pada lima hari pertama mencapai 0,062676 kg yang memiliki rata-rata suhu reaktor $30{ }^{\circ} \mathrm{C}$ dengan tekanan mencapai $103545 \mathrm{~N} / \mathrm{m}^{2}$. Hasil biogas terus mengalami peningkatan dimana puncaknya pada lima hari keempat dengan suhu rata-rata reaktor $28{ }^{0} \mathrm{C}$ dengan tekanan 103877,6 N/m menghasilkan biogas $0,063208 \mathrm{~kg}$, hanya saja pada hari selanjutnya biogas yang dihasilkan terus mengalami penurunan.

Dalam hal ini diduga semakin bertambahnya waktu fermentasi jumlah bakteri yang terkandung pada percobaan II tidak seimbang dengan ketersedian nutrient yang lebih sedikit dan juga padatan terlarutnya semakin tinggi sehingga perkembang biakan dan degradasi dari selulosa, hemiselulosa dan lignin untuk dijadikan senyawa yang dibutuhkan oleh mikroorganisme penghasil biogas menjadi redah sehingga mengakibatkan tekanan biogas menjadi rendah. Stater yang digunakan dalam produksi biogas dari eceng gondok pada percobaan kedua ini adalah kotoran sapi. Penggunaan kotoran sapi sebagai stater didasarkan atas proses produksi biogas dari kotoran sapi yang tidak mengunakan biakan mikroba ataupun stater maupun biang. Keadaan tersebut memberikan keterangan dalam kotoran sapi telah terdapat mikroba yang berperan dalam proses produksi biogas.

Sedangkan pada percobaan ketiga menggunakan dua stater sekaligus dimana 
stater EM4 1,8 kg dan stater kotoran sapi $3 \mathrm{~kg}$ berdasarkan data yang diperoleh pada penelitian hasil tertinggi terdapat pada lima hari keempat dimana suhu rata-rata reaktor 29 ${ }^{0} \mathrm{C}$ dengan tekanan 102979,9 $\mathrm{N} / \mathrm{m}^{2}$ menghasilkan biogas sebesar 0,062496 kg, hanya saja pada hari selajutnya terus mengalami penurunan. Hasil pengamatan rendemen produksi biogas pada perbandingan ketiga menunjukan bahwa penurunan rendemen biogas yang dihasilkan pada penggunaan dua stater sekaligus diduga disebabkan jumlah mikroba yang tidak seimbang melebehi ketersedian nutrient yang lebih sedikit dan juga padatan terlarutnya cukup rendah sehingga perkembang biakan mikroba menurun. Padatan terlarut sangat berpengaruh terhadap produksi biogas. Produksi biogas akan menurun jika padatan terlarutnya rendah. Demikian sebaliknya produksi biogas akan menurun jika padatan terlarutnya terlalu tinggi. Dari ketiga percobaan tersebut dapat diambil kesimpulan yang paling baik yaitu pada percobaan I dengan total massa biogas sebesar $0,379034 \mathrm{~kg}$

\section{KESIMPULAN}

Berdasarkan penelitian yang telah dilakukan, maka dapat diambil kesimpulan sebagai berikut :

1. Dari ketiga percobaan, menghasilkan tekanan pada percobaan I sebesar 104165,72 N/m ${ }^{2}$ selanjutnya tekanan pada percobaan II $103139,4 \mathrm{~N} / \mathrm{m}^{2}$ dan tekanan pada percobaan III mencapai 102324,98 N/ $\mathrm{m}^{2}$, sehinga hasil terbaik dengan tekanan terbesar didapat pada percobaan I.

2. Berdasarkan penelitian dari ketiga percobaan tersebut pada percobaan I memperoleh massa biogas total sebesar $0,379034 \mathrm{~kg}$ sedangkan percobaan II memperoleh massa biogas sebesar $0,375274 \mathrm{~kg}$ dan pada percobaan III memperoleh massa biogas sebesar 0,372266 $\mathrm{kg}$, maka massa biogas terbesar yaitu pada percobaan I.

3. Dari ketiga percobaan diperoleh laju aliran massa biogas pada percobaan I yaitu $0,0126345 \mathrm{~kg} /$ hari selanjutnya percobaan II memperoleh laju aliran massa biogas

mencapai $0,0125091 \mathrm{~kg} / \mathrm{hari}$ sedangkan percobaan III memperoleh massa biogas sebesar $0,0124089 \mathrm{~kg} /$ hari, maka laju aliran massa biogas terbesar yaitu pada percobaan I.

\section{DAFTAR PUSTAKA}

1. Alian Rahman. 2009. Pengaruh Pemanfaatan Sekat Dalam Ruang Digester Kotoran Sapi Terhadap Kapasitas Biogas. Fakultas Teknik. Universitas Brawijaya Malang

2. Ana Nurhasanah. 2006. Perkembangan Digester Biogas Di Indonesia - BPTP NTB

3. Anugrah Adi Santoso. 2010. Produksi Biogas Dari Limbah Rumah Makan Melalui Peningkatan Suhu Dan Penambahan Urea Pada Perombakan Anaerob. Universitas Sebelas Maret

4. Arnold Yonathan, Avianda Rusba Prasetya, Bambang Pramudono. 2013. Produksi Biogas Dari Eceng Gondok (Aichhornia Crassipes):Kajian Konsistensi Dan pH Terhadap Biogas Dihasilkan. Universitas Diponegoro

5. Dwi Setiana Wati. 2011. Pembuatan Biogas Dari Limbah Cair Industri Bioetanol Melalui Proses Anaerob (Fermentasi). Universitas Diponegoro.

6. I Gusti Made Sanjaya. 2010. Biokonversi Sampah Organik Pasar Menjadi Biogas Menggunakan Stater Effektive Micro Organisme (EM4). Universitas Negeri Surabaya.

7. Irvan. 2012. Pembuatan Biogas Dari Berbagi Limbah Cair Pabrik Kelapa Sawit. USU Medan. Jurnal Teknik Kimia.

8. Roy Renatha Saputro. 2009. Pembuatan Biogas Dari Limbah Peternakan. Universitas Diponegoro

9. Sakinah. 2012. Pengaruh Kosentrasi Biostater Kotoran Sapi Dan Kotoran Ayam Pada Produksi Biogas Dengan Menggunakan Limbah Jerami Padi. Universitas Hasanuddin

10. Sriwahyuni. 2011. Menghasilkan Biogas Dari Aneka Limbah

11. Wiranto Aris Munandar. 1983. Penggerak Mula Motor Bakar Torak. Penerbit ITB 